\title{
HIV/AIDS care: analysis of actions and health services integration
}

\author{
Assistência ao HIV/aids: análise da integração de ações e serviços de saúde
} Asistencia al VIH/SIDA: análisis de la integración de acciones de y servicios de salud

\author{
Gabriela Tavares Magnabosco ${ }^{1}$ (D) \\ Lívia Maria Lopes ${ }^{2}$ \\ Rubia Laine de Paula Andrade ${ }^{1}$ (C) \\ Maria Eugênia Firmino Brunello ${ }^{1}$ (1) \\ Aline Aparecida Monroe ${ }^{1}$ (i) \\ Tereza Cristina Scatena Villa ${ }^{1}$ (iD
}

1. Universidade de São Paulo.

Ribeirão Preto, SP, Brasil.

2. Centro Universitário Municipal de Franca.

Franca, SP, Brasil.
Corresponding author:

Gabriela Tavares Magnabosco.

E-mail: gabimagnabosco@hotmail.com

Submitted on $01 / 16 / 2018$.

Accepted on 05/29/2018.

DOI: 10.1590/2177-9465-EAN-2018-0015

\section{Abstract}

Objective: To analyze the integration of actions and health services in care provided by Specialized Services (SS) in Ribeirão Preto/SP in people living with HIV/AIDS (PLWHA) perception. Methods: Exploratory descriptive study, survey type in which 253 PLWHA were interviewed using a structured questionnaire. The data were analyzed by indicators (classified as unsatisfactoryaverage from 1 to 2.5; regular-between 2.6 and 3.5; satisfying-3.6 to 5) and multiple correspondence analysis. Results: The integration of health care actions had an average $3.7(\mathrm{SD}=1.7)$ classified as satisfactory. The horizontal integration was satisfactory regarding the use of medical records, and the vertical one regarding the referral to other health services. The low utilization of Basic Care and Emergency Care services was also identified. Conclusion: Despite of the satisfactory rating on the integration of assistance to PLWHA, challenges still be done, highlighting the need for greater empowerment of individuals and strengthening reference mechanisms with support of SCS to other points of attention in HIV/AIDS specificities.

Keywords: HIV; Acquired Immunodeficiency Syndrome; Chronic Disease; Health Systems.

\section{Resumo}

Objetivo: Analisar a integração das ações e serviços de saúde na assistência às Pessoas Vivendo com HIV/aids (PVHA), pelos Serviços de Atenção Especializada ao HIV/aids (SAE) de Ribeirão Preto-SP. Métodos: Estudo descritivo exploratório do tipo inquérito. Foram entrevistadas 253 PVHA mediante questionário estruturado. Os dados foram analisados por indicadores classificados em: insatisfatórios - médias de 1 a 2,5; regular - entre 2,6 e 3,5; satisfatórios - de 3,6 a 5; e análise de correspondência múltipla. Resultados: A integração das ações de saúde na assistência às PVHA obteve média 3,7 (dp=1,7), satisfatória. A integração horizontal foi satisfatória quanto ao uso do prontuário nas consultas, e a vertical quanto ao encaminhamento a outros serviços de saúde. Encontrou-se baixa utilização da Atenção Básica e Pronto-Atendimento. Conclusão: Há necessidade de empoderamento dos indivíduos com fornecimento de resultados de exames, fortalecimento da referência/contrarreferência e retaguarda dos SAE a outros serviços que atendem HIV/aids.

Palavras-chave: HIV; Síndrome de Imunodeficiência Adquirida; Doença Crônica; Sistemas de Saúde.

\section{Resumen}

Objetivo: Analizar la integración de acciones y servicios de salud en la asistencia prestado en los servicios de atención especializada (SAE) de Ribeirão Preto/SP sob la percepción de las personas viviendo con VIH/SIDA (PVVS). Métodos: Se realizó un estudio descriptivo exploratorio cuantitativo de encuesta. 253 PVS fueron entrevistadas con un cuestionario estructurado. Los datos en rangos de respuesta de 1 a 5 se analizaron por la construcción de indicadores según: insatisfactorio 1 a 2,5; regular entre 2,6 y 3,5; satisfactorio 3,6 a 5 y el análisis de correspondencia múltiple. Resultados: La integración de las actividades de salud a las PVS obtuvo 3,7 (SD = 1,7), satisfactoria. La integración horizontal fue satisfactoria en cuanto al uso del prontuario en las consultas y la vertical en cuanto al encaminamiento a otros servicios de salud. Fue observado baja utilización de la atención primaria y urgencias. Conclusión: A pesar de la calificación satisfactoria a la integración en la atención del VIH/SIDA, todavía existe la necesidad de capacitación de los individuos con los resultados de las pruebas y el fortalecimiento de la referencia con el respaldo del SAE para otros servicios de acuerdo con las características específicas de VIH/SIDA.

Palabras clave: VIH; Síndrome de Inmunodeficiencia Adquirida; Enfermedad Crónica; Sistemas de Salud. 


\section{INTRODUCTION}

From the onset of the epidemic to the current situation, HIV/ aids went through the transition of an accute mortal disease to a chronic condition that brings with itself, beyond it's dimension and biological complexity, social, cultural and psychological unfolding such as stigma and discrimination, medication with complex schemes, difficulties on treatment adherence, side effects, among others. ${ }^{1,2}$

It is estimated that, daily, more than 7.000 people are infected with HIV wolrdwide, and in 2015, there were 2,1 million new HIV infections, which resulted in 36,7 million people living with HIV/aids (PLHA). ${ }^{3}$ In Brazil, 798.366 cases of aids were notified until June 2015, being estimated 781 thousand PLHA in Brazil, which represented a prevalence of $0,39 \%$. Of these people, $83 \%$ had a stabilished diagnosis and approximately $80 \%$ of these are linked to a health service, of which only $66 \%$ remained in follow-up. ${ }^{4}$ Between 2010 and 2015, the country registered 40.6 mil cases of aids, being 17 thousand on the southeast region. On the year 2012, the city of Ribeirão Preto/ SP presented detection rates (27.2/100 thousand inhabitants) and mortality (8.9/100 thousand inhabitants) by aids higher than average of the State of São Paulo, which registered average of 20,3 and 6,6/100 thousand inhabitants, respetitively. ${ }^{4}$

According to the aforementioned scenario, the prevention and control of HIV/aids, together with hospital admissions and deaths due to illness, appear as challenges to public policies that aimed at strengthening the health care system, since the has occurred in a context where services are configured as essentially reactive, fragmented and episodic.

This way, it considers that management of HIV/aids require production of a full, integrated and resolutive care, ${ }^{5-7}$ so that there is a durable articulation of the clinical practices, that is, that persists throughout the care process aiming at the continuity and the totality of the services required in the care and provided by different professionals and organizations..$^{8,9}$

In this sense, such care must construct itself on práxis of teams and health services through interactions between users and professionals, as well as among professionals and among different health services. ${ }^{9-12}$

This way, composition of an effective care network that are accessible and coherent with care demands of PLHA implicates on recognizing the need of an effective integration of offered actions inside each specialized health service - horizontal integration, as different points of attention of care network vertical integration. ${ }^{1,2,12}$

Thus, the present study aims to analyze integration of actions and health services on care provided by Specialized Care Services to HIV/aids (SCS) of the municipality of Ribeirão Preto/SP under the perception of PLHA.

\section{METHODS}

It is an epidemiologic descriptive study of the inquiry type, developed in Ribeirão Preto which estimated population in 2015 was of 666.323 inhabitants. ${ }^{13}$ The municipality was Pioneer in the country on implementation of actions and services for HIV/aids management on local care network and registered a total of 791 new cases of aids on the Information System of Diseases Related (SINAN) in the last five years. ${ }^{4}$ In 2012 , the health care network of the municipality was structured in five Health Districts, having 42 serviços de of Primary Health Care (Primary Health Care Unit-PHC and Family Health Unit-FHU), five units of Secondary/ Tertiary Care (District Health Units - DHU) that assist diverse spacialities and four of them offered emergency room (ER), an emergency care unit (ECU) and three hospitals. ${ }^{14}$

With regard to the diagnosis of HIV/aids, all the health units of the public network of the municipality (PHC, DHU, ER e Hospitals) could ask for an anti-HIV exam and in case of positive diagnosis, the individual was sent to one of SCS of the municipality, which was distributed in five health districts and operated with specialized teams, providing services such as Home Care Service (HCS) and Testing and Counseling Centers (TCC). Five TCC of the municipality offered Quick Diagnosis Test for HIV with result emission in 30 minutes. $^{14}$

Clinical-therapeutic follow up of HIV/aids cases residents in the municipality was developed at the SCS, designated in this study on the letters A, B, C, D and E. Such services were configurated in various forms in the municipality, being, SCS A, B and D characterized as reference centers in STI (Sexually Transmitted Infections)/aids - exclusive health units for care of STI/aids and coinfections such as tuberculosis, among others. SCS C and E were characterized as specialized outpatient clinics and provided care in various specialties. SCS A, B, C and $D$ worked from mondaay to friday full time offering medical consultation to PLHA each two to three months and had pharmacies at the own service. SCS E worked from Monday to Friday only in the afternoon, offering medical consultation to PLHA each three or four months; medication withdrawal happened in another health service.

Communication among teams of SCS occured through monthly reunions that served for discussions of clinical asspects, surveillance, diagnostic support and integration between services. Nursing professionals were the ones that participate the most on reunions, assuming the task of passing the information to the other members of your team. ${ }^{14}$

Cases that are more complex were sent to the Infectious Diseases Treatment Unit of the Clinical Hospital of the School of Medicine in Ribeirão Preto of University of São Paulo (HCFMRP/USP), which was reference for the region of municipality and enabled ambulatory care and partial or full admission (Day Hospital). ${ }^{14}$ 
Study's population was constituted by PLHA followed up on referred SCS of Ribeirão Preto. For inclusion in the study, inclusion criteria were considered: cases informed of HIV/aids, age equal or higher than 18 years old, residents in the municipality and not belonging to the prison system.

Number of confirmed cases of HIV/aids de HIV/aids followed by SCS in January was 1.389 individuals (249 at SCS A, 374 at B; 249 at $C ; 374$ at $D ; 143$ at $E)$. For sample calculus considered the sample error of $5 \%(e=0.05)$; confidence interval of $95 \%(Z=1.96)$ and $\mathrm{P}$ (populational proportion) of $50 \%$. Minimum sample of 358 individuals was obtained through equation $n_{0}=P .(1-P) \cdot Z^{2} / e^{2}$ and, after correction in relation to total population (1.389), resulted in 302 individuals to be considered for the study.

Sampling was done in two phases: stratification with proportional sharing according SCS responsible by invidual follow up, in a way that 54 individuals should have been interviewed at SCS $A ; 81$ at $B ; 54$ at $C ; 81$ at $D ;$ and 31 at $E$; and for convenience until reaching the amount of people expected to compose the sample. Thus, of 302 approached individuals, 49 refused to participate in the research, totalizing 253 interviewees.

For data collection, developed between January 2012 and May 2013, a structured questionaire elaborated for the present study based on other researches was used, "Evaluation of the quality of outpatient care in outpatient public services in public AIDS care services in Brazill", ${ }^{15}$ as well as "Ministry of Health Recommendations for TARV (Antiretroviral Therapy) in adults infected by HIV", ${ }^{16}$ on "Methodology for rapid evaluation of the organizational characteristics and performance of SUS basic care services", ${ }^{17}$ and on "Protocol of outpatient follow-up of the patient with HIV/aids of the Hospital Foundation of the State of Minas Gerais". ${ }^{18}$

In order to re-evaluate and verify the feasibility of the instrument, a content analysis was carried out with five experienced professionals on the subject of HIV/AIDS and a pilot test with interviews with 21 PLHA in follow-up in the SCS of the municipality for semantic analysis in order to verify the comprehensibility of the items for the target population and adaptation to local specificities. Final version of instrument used on the research was not scientifically validated. We highlight that in some cases classified through clinical guidelines was under definitive care of a secundary care point of view, which can constitute itself as an entering door of health system, counting with the support of other components of operational structure of Care Network. ${ }^{2}$

In these moldes, there are SCS, which are configurated as an important source of longitudinal and habitual, facilitating recognition of needs throughout the time and enabling offer of specified and systematic actions of health promotion, prevention and recuperation in order to assure care cordination to PLHA. This way, it should be noted that, in this study, it is believed that the instrument based on some attributes of primary care is also appropriate to evaluate SCS, since they act as a gateway and should promote a comprehensive and coordinated approach to the care provided to PLHAs.

Category of response of questions of the instrument that contemplated the Likert scale, with value between "one" and "five", which the more favorable answer corresponded to the higher value. For this study, we used the variables related to the dimension "integration of actions and health services for PLHA care", subdivided into:

a) Horizontal integration - defined as inter-relation among care takers on clinical practice with emphasis on continuity and globality of actions provided by different professionals and teams, articulated with time and space, according knowledge and available information. ${ }^{19}$ This session includes the following variables: the use of the medical records by the health professionals during the consultation, registration of complaints of individuals in the medical records, receipt of printed test results, information of the examination results during the consultations, information on the scheduling of the return.

b) Vertical Integration - defined as articulation between health services and actions referred to a given care practice in a way that, independently from the place where they are developed, they are focused on a common goal. ${ }^{20}$ In this section, variables are included: referral to other health services when needed; assistance of health professionals for the scheduling of consultations in other services, receipt of appointment scheduling in another health service, receipt of written information about the user to be delivered to another health service, obtaining care in another health service health, receipt of written information about care received at another health service; discussion about care in another health service; use of Primary Care units; use of Emergency Room; use of other health services.

c) On data analysis, indicators that correspond to an average score of answers of all interviewees for each question of the instrument were constructed. This way, each indicator was classified as insatisfatory $(\leq 2.5)$, regular (entre 2.6 e 3.5 ) or satisfatory $(\geq 3.6)$

In order to classify the integration of actions in the assistance to PLHA in the municipality as a whole, a composite index was measured, which corresponds to an average score of the responses of all the respondents for all variables of the instrument.

To finalize, it was developed Multiple Corresponsance Analysis (MCA) to verify existance of association between SCS of the municipality (passive variables) and active variables of the MCA, which were selected through Chi-square test. Level of statistical significance adopted was of $5 \%$. It is important to highlight that SCS E was considered as MCA for possessing a low number of respondents. 
Complying with Resolution no 196/96 of the National Concil of Health, in force at the time of the beginning of the research, this study was approved by the Research Ethics Comittee of the School of Nursing of Ribeirão Preto from University of São Paulo, according to protocol $n-1215 / 2010$. All the interviewees signed the informed consent form to participate in the research.

\section{RESULTS}

Integration of health actions onf caring for PLHA in the municipality of Ribeirão Preto obtained an average of 3.7 $(\mathrm{dp}=1.7)$, being classified as satisfatory.

Among indicators related to horizontal integration of care, only the indicator "receipt of printed test results" was considered regular. Other indicators were classified as satisfatory (Figure 1).

Figure 1. Distribution of average and confidence intervals de of integration variables of action among reference professional team, Ribeirão Preto, 2012-2013. V59: Utilization of medical records during the consultation; V60: Register of complaints of people living with HIV/aids on medical records; V61: Receipt of printed test results; V62: Information of test results during consultation; V63: Information about return scheduling date.

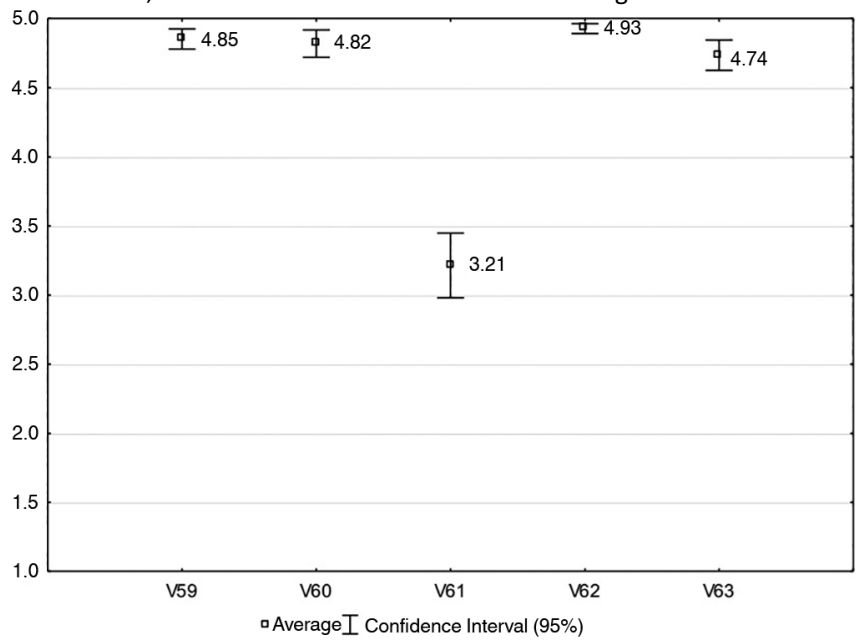

As for vertical integration, the "receipt of written information on the conduct of other health services" was considered insatisfatory. The indicator "discussion about results and conducts adopted by another health service" was considered regular. Other indicators were satisfatory (Figure 2).

Still on vertical integration, it was found a low utilization of Primary Care services, Emergency Room and other health services (Figure 3).

On Figure 4, it was verified that SCS A was located more distant than others (Quadrant 2) and had association with regular development on integration variables. Beyond that, this SCS had association with "almost always" utilization of PCU. SCS B and
Figure 2. Distribution of average and confidence intervals of integration variables of care with other services, Ribeirão Preto, 2012-2013. V73: Referral to other health services when needed; V74: Health professionals' help for scheduling consultations in other services; V75: Receipt of proof of appointment scheduling in another health service; V76: Receipt of written information about the user to be delivered to another health service; V77: Obtaining care at another health facility; V78: Receipt of written information on conduct adopted at another health service; V79: Discusion about conducts adopted by another health service.

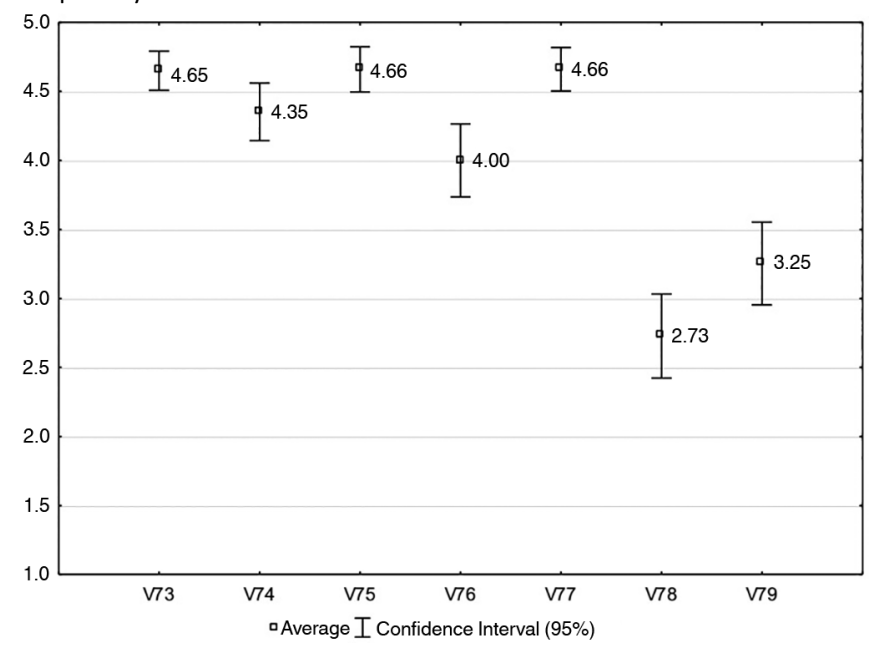

Figure 3. Distribution of average and confidence intervals of utilization of health services, Ribeirão Preto, 2012-2013. V70: Utilization of Primary Health Care Units; V71: Utilization of Emergency Room; V72: Utilization of other health services.

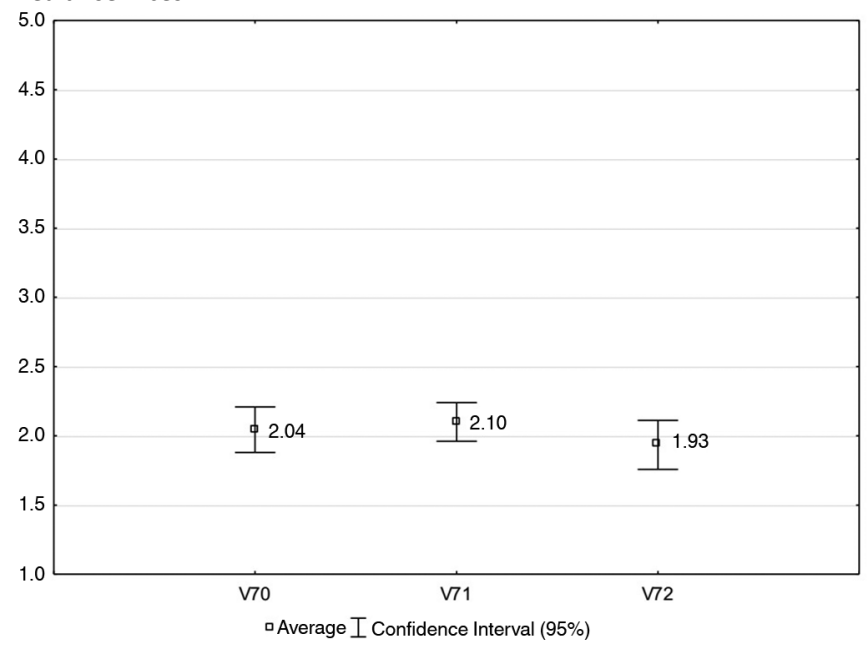

C (Quadrant 4) was associated with few utilization of PCU and ER, however they presented better integration of actions. SCS D (Quadrante 1) was associated to instatisfatory development in relation to integration, however its users used PCU and ER. (Figure 4). 
Figure 4. Factorial plan of the variables related to the integration of actions and health services by people living with HIV/aids, Ribeirão Preto, 2012-2013. V60: Register of complaints of individuals on medical records by health professionals; V61: Receipt of printed test results; V63: Return schedule information; V70: Utilization of Primary Health Care Units; V71: Utilization of Emergency Room; V73: Referral to other health services when needed; V74: Health professionals' help for scheduling consultations in other services; V75: Receipt of proof of appointment scheduling at another health facility; V79: Discussion about conducts adopted in another health service.

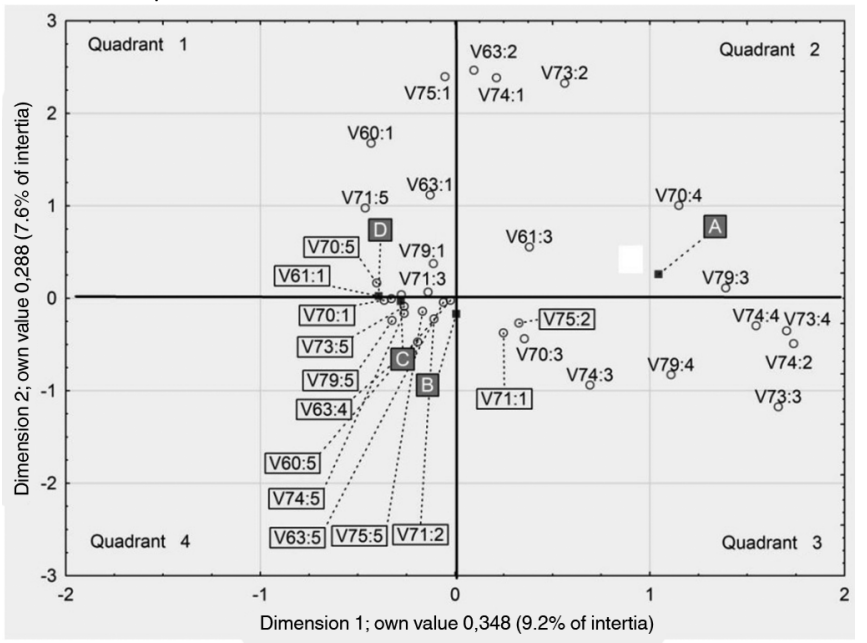

\section{DISCUSSION}

In relation to horizontal integration, it was found satisfatory eveluation results as for developing technical activities turned to the use of medical records and registration of complaints during consultations. Such indicators related themselves with appropriation of information for planning of care provided to individuals, once that, to have adequate care, are ways that help recognition, availability and transformation are necessary. ${ }^{21,22}$ However, reflections are pertinent as for quality, sharing and effective use of information, once that, the registries, in the case of integrated care, are configured as tools for the planning, implementation of health interventions and information flow between the different services. , $^{9,23}$

SCS presented a constancy as for diagnostic and therapeutic support when it comes to realization and divulgation of test results, however it was identified a deliver of printed results to PLHA not always happen effectively, fact that can difficult continuity and complementarity of care in other points of attention, being able to generate duplicity on realization of unnecessary exams and costs. ${ }^{2}$ The provision of information on the scheduling of return visits in the health service was also evaluated as satisfactory, which reinforces the commitment of the staff of the teams regarding the continuity of follow-up therapy.

Considering notes made, utilizing and embodying light technologies on developing full care becomes and important challenge of work routine, as these can be given necessary support for reception/bond, being these aspects lacking in health services and that aim shared construction of therapeutic projects in team and users, favoring care continuity. ${ }^{24}$ In this sense, the construction of more democratic relations in the health work space is a primordial issue to achieve horizontal integration.

As for vertical integration, it is highlighted as positive aspect of referral to other health services. It was verified that there is an evident concern of the SCS professionals regarding the scheduling and obtaining of the service in other services, however the users informed that the discussion of the conducts carried out in these happens in an insipient way by the SCS team. Such situation is unfavourable to resolutivity and continuity of care, becoming an important barrier to be worked with professionals in the sense of reinforce the importance of construction of a followup that integrate diverse specialities, interventions and health services to assist to existing demands.

Still related to vertical integration, the provision of the reference guide was assessed as satisfactory among individuals who had already been referred. The counter-referral was evaluated as unsatisfactory, which may interfere in the continuity of care provided, ${ }^{9,19}$ given that, when anu ser return to the unit of origin with information about his/her assessment in anohter service, the higher the chances to promote a humanized and resolutive practice. It is reinforced that, in order for the care process to be consolidated through a network of attention, the need to establish regular and regulated connections among health services emerges, with a view to the interaction between them. Within this scope, the main strategic components are the processes of reference and counter-referencing, which in turn need to be formalized through the registration of information and sharing of information, in order to guarantee the flow of information and the continuity of care.

In a previous scientific study the authors point out that the integration of actions and services could be favored if, in fact, there were mechanisms of regulation, besides reference and counterreference. ${ }^{25}$ Following this train of thought, it is understood that construction of health care networks, to favour equity and care integrality, must be supported by quality information, offered by systems of information in appropriated health. ${ }^{2}$

Systems of information in health constitute an important resource in relation to the knowledge and situational diagnosis of the different health realities. Imprint an integrated effort to collect, report and use infromation and knowledge to influence care planning, program management, policies and health research, in line with identified needs. For such, they comprehend social determinants of health and legal operacionalization of systems and networks of health care, considering inputs, structured resources and processes of health care, political and operational organization, human and financial resources, and results produced by teams. ${ }^{25}$

Along the last years, it is noted considerable advances on access and possibilities of analysis of main systems of information in health available in Brazil, related, mainly, to the decentralization 
of processing by States and municipalities, allied to ongrowing technological development in the area of information. Still like this, difficulties in the care process faced by some SCS teams are recurrent, mainly on what on what is related to articulation to offer and effectiveness of integrated care. It is understood that these difficulties contribute to the fragmentation of care, which, given the complexity of HIV/aids, is seen as a major barrier in the execution of integral care. ${ }^{26}$

Another pertinent reflection on this aspect is turned to the historic verticalization of programs that doesn't correspond to needs and realities of users and of the own organization and conformation of networks of health care. ${ }^{24}$ For the author, thinking on vertical integration requires (re)signification of practices and of hierarchical limits of brazilian health system, putting SCS as coparticipant and coresponsible for the identification of several demands of the individual, being related to prevention, treatment and/or insertion on reality ando $f$ it's "transit" by the network, privileging the follow-up of care. ${ }^{24}$

Regarding utilization of other health services, it was evident that PLHA do not use PC and ER services that compose the municipality network attention with frequence. In this context, it is important to emphasize the fact that PCU do not meet some specifities inherent to HIV/aids, restricting them to refer to the SCS or other specialized services. In order for these services to be complementary resources to be inserted and activated in the care process for these subjects, it is necessary that they have trained teams that understand the real needs of the demand served, from prevention to rehabilitation, as well as the backside available in the different services. ${ }^{6,26}$ However, it's needed to reinforce the important role developed by SCS on resolutivity and integration of provided care, with amplifying access to promotion and prevention actions, as well as consultations and specialized procedures, articulating points of care that are distant. ${ }^{27}$

There is to reflect still, about the complexity of integration of care in situations in which users chose a follow-up in SCS outside of the area of coverage to which they belong mainly on what it's referred to conditions of access to health services, but also to the articulation and flow of information established between the services of the network.

Thus, to manage chronic conditions of HIV/aids complexity, there is the need to think in an integrated health system, which presupposes an organized offer of assistance and an articulated network, with flows and paths defined, ordered and compatible with the demand. ${ }^{2}$ For this, it's indispensable shared elaboration of clinical and sanitary guidelines among SCS team members and of other services, considering pratices of support and the back-up of other services as one of the possible alternatives to the different vulnerabilities inherent to HIV/aids. It's important to highlight, in this sense, that the realization of monthly meetings between the coodination from the City Program of HIV/ainds and SCS professionals can be a positive strategy on the conception of integrated care plan, once it enables discussion of cases/ situations and the sharing of information and knowledge.

The integration of actions in PLHA by SCS of Ribeirão Preto, of general form, was evaluated as satisfatory. However, it was verified that the better the integration, both horizontal and vertical, the less the use of PC and ER services. This way, it is believed that teams of SCS enable a better integration for having successful identification of the demands of the users and can solve the problems in the SCS itself.

In this same sense, it was also verified that the lower the integration the greater the use of the PCU and ER, as observed in SCS D (Figure 4). This finding evidences that the SCS team may not be identifying the needs of the users who, then, search for other services, such as the PCU and ER, to solve their problems.

Regarding the findings of the study, we recognize the existence of some limitations of the study as the possibility of occurrence of memory bias due to the questioning about behaviors performed long ago, understanding bias, referring to the personal understanding that the individuals could present before certain questions and selection bias due to convenience sampling, allowing only the inclusion of those individuals who attended the service at the time of data collection. In addition, the study contemplated only the perception of a single actor, the users, which could be impregnated by personal and subjective components that involve satisfaction with the service rendered, the understanding of what the service could/should offer, the bonding and dynamics of interaction with health professionals.

\section{CONCLUSIONS}

In the studied municipality, integration of actions and servies on caring for HIV/aids had a satisfatory evaluation on caring for PLHA, which is characterized by programmatic actions with municipal coordination that articulates different actions and services of clinical-laboratory support and counts on the performance of specialized services with teams qualified for such. Thus, the findings of the study show gaps in relation to the use of the other services of the care network, which may be related to the resolution of users' demands in the SCS, or to the fact that other services, such as the PCU still do not specific characteristics inherent to HIV/aids.

As challenges to the horizontal and vertical integration of PLHA care, are the need for greater empowerment of individuals with the provision of test results that reflect the evolution of their clinical condition and can be used in other care. Beyond that, it's necessary the strengthening of referral and counter-referral mechanisms and matrix support, with the SCSs themselves as back-up services for the other points of attention in meeting the various specificities that involve HIV/aids.

It was verified that the chronicity assumed by HIV/aids imposes a burden on health services by exposing the shortcomings 
that exist in the process of planning integrated care and posing a challenge to professionals, health teams and managers. It is essential that there is a durable articulation of the clinical practices, aiming to ensure the continuity and the overall care provided.

\section{FUNDING SUPPORT}

Foundation for Research Support of the State of São Paulo FAPESP (PhD scholarship - Process 2010/15521-8).

\section{REFERENCES}

1. Figueiredo LA, Lopes LM, Magnabosco GT, Andrade RLP, Faria MF, Goulart VC, et al. Provision of health care actions and services for the management of HIV/AIDS from the users' perspective. Rev Esc Enferm USP [Internet] 2014; [cited 2016 Apr 4]; 48(6):1024-31. Available from: http://www.scielo. br/pdf/reeusp/v48n6/0080-6234-reeusp-48-06-1026.pdf

2. Mendes EV. A construção social da atenção primária à saúde. Brasília (DF): Conselho Nacional de Secretários de Saúde - CONASS; 2015.

3. United Nations Programme on HIV/AIDS (UNAIDS)/World Health Organization (WHO). Diagnostics Access Initiative to achieve the 9090-90 treatment target. Geneva: UNAIDS; 2015

4. Ministério da Saúde (BR). Secretaria de Vigilância em Saúde Departamento de DST, Aids e Hepatites Virais. Boletim Epidemiológico HIV/Aids 2016. Brasília (DF): Ministério da Saúde; 2016.

5. Kadri MR, Schweickardt JC. As Organizações da Sociedade Civil no enfrentamento à AIDS no Amazonas, Brasil. Ciênc Saúde Coletiva [Internet]. 2015; [cited 2017 Oct. 10]; 20(5):1331-9. Available from: http:// www.scielosp.org/pdf/csc/v20n5/1413-8123-csc-20-05-01331.pdf

6. Silva SF. Organização de redes regionalizadas e integradas de atenção à saúde: desafios do Sistema Único de Saúde (Brasil). Ciênc Saúde Coletiva [Internet]. 2011; [cited 2016 Apr 10]; 16(6):2753-62. Available from: http://www.scielo.br/pdf/csc/v16n6/14.pdf

7. Silva MVS, Miranda GBN, Andrade MA. Sentidos atribuídos à integralidade: entre o que é preconizado e vivido na equipe multidisciplinar Interface (Botucatu) [Internet]. 2017; [cited 2017 Oct 17]; 21(62):58999. Available from: http://www.scielo.br/scielo.php?pid=S141432832017000300589\&script=sci_abstract\&tlng=pt

8. Odeny TA, Penner J, Lewis-Kulzer J, Leslie HH, Shade SB, Adero W, et al. Integration of HIV Care with Primary Health Care Services: Effect on Patient Satisfaction and Stigma in Rural Kenya. AIDS Res Treat [Internet] 2013; [cited 2017 Oct 13]; 2013:485715. Available from: https://www. ncbi.nlm.nih.gov/pubmed/?term=Integration+of+HIV+Care+with+Prim ary+Health+Care+Services\%3A+Effect+on+Patient+Satisfaction+and +Stigma+in+Rural+Kenya

9. Bousquat A, Giovanella L, Campos EMS, Almeida PF, Martins C, Mota $\mathrm{PHS}$, et al. Atenção primária à saúde e coordenação do cuidado nas regiões de saúde: perspectiva de gestores e usuários. Ciênc Saúde Coletiva [Internet]. 2017; [cited 2017 Oct 17]; 22(4):1141-54. Available from: http://www.scielo.br/pdf/csc/v22n4/1413-8123-csc-22-04-1141.pdf

10. Silva KL, Sena RR. Comprehensive health care: indications from the training of nurses. Rev Esc Enferm USP [Internet]. 2008; [cited 2016 Apr 10]; 42(1):48-56. Available from: http://www.scielo.br/pdf/reeusp/ v42n1/07.pdf

11. Mattos RA. Integralidade e a formulação de políticas específicas de saúde. In: Pinheiro R, Mattos RA, orgs. Construção da integralidade: cotidiano, saberes e práticas em saúde. Rio de Janeiro (RJ): ABRASCO; 2003. p. $45-59$.

12. Lopes LM, Magnabosco GT, Andrade RLP, Ponce MAZ, Wysocki $A D$, Ravanholi GM, et al. Coordenação da assistência prestada às pessoas que vivem com HIV/AIDS em um município do Estado de São Paulo, Brasil. Cad Saúde Pública [Internet]. 2014; [cited 2016 Mar 4]; 30(11):2283-97. Available from: http://www.scielo.br/pdf/csp/ v30n11/0102-311X-csp-30-11-2283.pdf
13. Instituto Brasileiro de Geografia e Estatística (IBGE) (BR). Panorama populacional Ribeirão Preto-SP [Internet]. 2014; [cited 2014 May 12] Available from: https://cidades.ibge.gov.br/brasil/sp/ribeirao-preto/ panorama

14. Magnabosco GT, Lopes LM, Andrade RLP, Brunello MEF, Monroe AA, Villa TCS. Tuberculosis control in people living with HIV/AIDS. Rev Latino Am Enferm [Internet]. 2016 Sep; [cited 2018 May 25]; 24:e2798. Available from: http://www.scielo.br/scielo.php?script=sci_arttext\&pid $=$ S0104-11692016000100410

15. Nemes MIB, Alencar TMD, Basso CR, Castanheira ERL, Melchior R Alves MTSSB, et al. Avaliação de serviços de assistência ambulatoria em aids, Brasil: estudo comparativo 2001/2007. Rev Saúde Pública [Internet]. 2013; [cited 2017 Oct 13]; 47(1):137-46. Available from: http:// www.scielo.br/pdf/rsp/v47n1/18.pdf

16. Ministério da Saúde (BR). Secretaria de Vigilância em Saúde. Programa Nacional de DST e AIDS. Protocolo Clínico e Diretrizes Terapêuticas para Manejo da infecção pelo HIV em adultos. Brasília (DF): Ministério da Saúde; 2017. Available from: http://conitec.gov.br/images/Consultas/ Relatorios/2017/Relatorio_PCDT_ManejoInfeccaoHIVadultos_CP.pdf

17. Almeida CM, Macinko J. Validação de uma metodologia de avaliação rápida das características organizacionais e do desempenho dos serviços de atenção básica do Sistema Único de Saúde (SUS) em níve local. Brasília: OPAS; 2006.

18. Fundação Hospitalar do Estado de Minas Gerais. Protocolo de Acompanhamento Ambulatorial do Paciente com HIV/AIDS. Belo Horizonte: FHEMIG; 2013.

19. Hartz ZMA, Contandriopoulos AP. Integralidade da atenção e integração de serviços de saúde: desafios para avaliar a implantação de um "sistema sem muros". Cad Saúde Pública [Internet]. 2004; [cited 2016 Jan 10]; 20(Supl.2):S331-6. Available from: http://www.scielo.br/pdf/ csp/v20s2/26.pdf

20. Núñez RT, Lorenzo IV, Naverrete ML. La coordinación entre niveles asistenciales: una sistematización de sus instrumentos y medidas. Gac Sanit [Internet]. 2006; [cited 2016 Mar 2]; 20(6):485-95. Available from: http://www.scielosp.org/pdf/gs/v20n6/revision.pdf

21. Arruda C, Lopes SGR, Koerich MHAL, Winck DR, Meirelles BHS, Mello ALSF. Redes de atenção à saúde sob a luz da teoria da complexidade. Esc Anna Nery [Internet]. 2015; [cited 2017 Oct 14]; 19(1):169-73. Available from: http://www.scielo.br/pdf/ean/v19n1/1414-8145ean-19-01-0169.pdf

22. Starfield B. Atenção primária: equilíbrio entre necessidades de saúde serviços e tecnologia. Brasília: Organização das Nações Unidas para a Educação, a Ciência e a Cultura; 2002.

23. Rivera FJU, Artmann E. Inovação e agir comunicativo: redes e tecnologias de gestão para a saúde. Cad Saúde Pública [Internet].2016 [cited 2017 Oct 15]; 32(Sup 2):e00177014. Available from: http://www. scielo.br/pdf/csp/v32s2/pt_1678-4464-csp-32-s2-e00177014.pdf

24. Bonfada D, Cavalcante JRLP, Araujo DP, Guimarães J. A integralidade da atenção à saúde como eixo da organização tecnológica nos serviços. Ciênc Saúde Coletiva [Internet]. 2012; [cited 2016 Apr 12]; 17(2):555-60. Available from: http://www.scielo.br/pdf/csc/v17n2/a28v17n2.pdf

25. Giovanella L, Almeida PF. Atenção primária integral e sistemas segmentados de saúde na América do Sul. Cad Saúde Pública [Internet]. 2017; [cited 2017 Oct 17]; 33(Supl 2):e00118816. Available from: http:// www.scielo.br/pdf/csp/v33s2/1678-4464-csp-33-s2-e00118816.pdf

26. Borges MJ, Sampaio AS, Gurgel IG. Trabalho em equipe e interdisciplinaridade: desafios para a efetivação da integralidade na assistência ambulatorial às pessoas vivendo com HIV/Aids em Pernambuco. Ciênc Saúde Coletiva [Internet].2012; [cited 2016 Apr 10]; 17(1):147-56. Available from: http://www.scielo.br/pdf/csc/v17n1/a17v17n1.pdf

27. Erdmann AL, Andrade SR, Mello ALSF, Drago LC. Secondary Health Care: best practices in the health services network. Rev Latino Am Enferm [Internet]. 2013; [cited 2016 Apr 10];21(no.esp):131-9. Available from: http://www.scielo.br/pdf/rlae/v21nspe/17.pdf 